\title{
BROWNTOP AND PASTURE NUTRITION
}

\author{
R. H. Jackman and M. C. H. Mouat \\ Grasslands Division, DSIR, Palmerston North
}

Abstract

Pot experiments have shown that browntop is more efficient in utilizing scarce phosphate than is white clover when white clover is obtaining nitrogen either from fixation or from the soil. There is evidence that browntop can reduce the amount of phosphate available to clover both by direct competition and by decreasing the soil moisture and hence the availability of phosphate. These effects are probably not peculiar to browntop which, however, does have a mat that can effectively shade clover stolons thereby reducing the activity of clover stolon nodes and the ability of clover to regrow leaf. Reduced phosphate availability and stolon shading exert a powerful control on clover growth and this control is likely to be strongly expressed on set-stocked hill country, particularly if the soil has a high P flxing capacity and easily dries out.

\section{INTRODUCTION}

AN important immitation to the production of hill country browntop pastures is $\mathrm{N}$ deficiency. This results from inadequate clover growth and $\mathrm{N}$ fixation which in turn appear to be particularly dependent upon the availability of $\mathrm{P}$.

This paper is concerned with some effects of browntop on the $P$ available to white clover and upon the ability of clover to respond to $\mathrm{P}$.

\section{ABILITIES OF BROWNTOP AND WHITE CLOVER TO} OBTAIN SCARCE P

The responses of white clover and browntop to $\mathrm{P}$ were found by growing them in pots using a P-deficient soil (Jackman and Mouat, 1972). Increasing amounts of $P$ were mixed throughout the soil and ammonium nitrate was supplied to the browntop sufficient to maintain a fully adequate $\mathrm{N}$ content in the browntop ( $>4.5$ to $5.2 \% \mathrm{~N}$ at harvest). Moisture was maintained at near field capacity by daily watering to weight. The plants were harvested at 38 days after planting germinated seed. 
TABLE 1: RELATIVE HERBAGE YIELDS (\%) OF BROWNTOP AND WHITE CLOVER AND P CONTENTS (\%) WHEN RESPONDING TO P

\begin{tabular}{|c|c|c|c|c|c|c|c|c|}
\hline & & & & \multicolumn{5}{|c|}{ P Applied $(p p m)$} \\
\hline & & & & 12 & 24 & 48 & 96 & 192 \\
\hline \multicolumn{9}{|c|}{ Relative herbage DM: } \\
\hline Browntop & $\ldots$ & $\ldots$ & $\ldots$ & 39 & 69 & 93 & 100 & 100 \\
\hline White clover & . & & & 19 & 30 & 52 & 86 & 100 \\
\hline \multicolumn{9}{|l|}{$\mathrm{P}$ contents: } \\
\hline Browntop & & & & 0.24 & 0.29 & 0.40 & 0.54 & 0.69 \\
\hline White clover & & & & 0.27 & 0.31 & 0.33 & 0.46 & 0.59 \\
\hline
\end{tabular}

Table 1 gives some pertinent results.

If the $\mathrm{P}$ supply was suboptimal, then the growth of white clover was more severely affected than was the growth of brown-

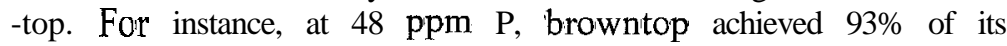
maximum growth rate but white clover reached only $52 \%$.

This experiment used very $\mathrm{N}$-deficient soil. It has been repeated using a P-deficient soil with a better $\mathrm{N}$ supply to which fertilizer $\mathrm{N}$ had. been added. The added $\mathrm{N}$ was sufficient to inhibit nodule activity. Preliminary results show no change in the pattern of response shown in Table 1 . It can be concluded that young clover plants, whether dependent upon their own symbiotically fixed $\mathrm{N}$ or $\mathrm{N}$ supplied from the soil, are less 'able to obtain scarce $\mathrm{P}$ than is browntop. Noteworthy also is the fact that browntop continued to accumulate $P$ when the growth response to additional $P$ had ceased.

These plants were young. It is likely that if they had been older the relative yields at lower $\mathrm{P}$ levels would have been higher but it is not known if the differences between the two plants would have altered.

\section{EFFECTS OF BROWNTOP ON CLOVER}

These effects can be grouped under the headings (1) $\mathrm{P}$ available to clover, and (2) ability of the clover to respond to the $\mathrm{P}$ available to it.

\section{P Available to Clover}

Phosphate mainly reaches' a root by diffusion in the soil solution. This takes place because the root takes up $\mathrm{P}$ and reduces the $\mathrm{P}$ concentration in the soil solution immediately around it- 
self. If, then, clover and grass roots come so close together that the zones of reduced $\mathrm{P}$ overlap, the concentration of $\mathrm{P}$ available to each plant will be reduced. Table 1 shows that this would be more detrimental to clover than to browntop. This overlap of feeding zones occurs if the roots are 1 to $2 \mathrm{~mm}$ apart.

It has been found that ryegrass roots reach this proximity when the plants are grown in pots (Jackman and Mouat, 1972). Browntop root systems are similar and presumably the same situation applies. Hence a clover root penetrating amongst these grass roots would be in direct competition with the grass roots for P.

Support for this conclusion was obtained from results of placing radioactive $\mathrm{P}$ at different depths under 3-year-old mown browntop-white clover swards growing on a loamy fine sand very deficient in $\mathrm{N}$ and $\mathrm{P}$ and having a very low $\mathrm{P}$ fixing capacity. Subsequent measurement of the radioactive $\mathrm{P}$ in the herbage allowed the root activity for $\mathrm{P}$ uptake at the varying depths in the soil to be calculated.

Available P test figures of some of the plots are given in Table 2 and show that most of the applied $\mathrm{P}$ had remained in the top $2.5 \mathrm{~cm}$ of soil.

TABLE 2: AVAILABLE P TEST FIGURES AT DIFFERENT SOIL DEPTHS

Olsen's Method - (ppm P soil bases),/4

\begin{tabular}{|c|c|c|c|c|c|c|}
\hline \multirow[b]{2}{*}{ Soil Depth (cm) } & & & \multicolumn{4}{|c|}{ Superphosphate $(\mathrm{kg} / \mathrm{ha} / \mathrm{yr})$} \\
\hline & & & 0 & 168 & 500 & 896 \\
\hline 0 to 2.5 & & 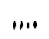 & 4 & 5 & 20 & 38 \\
\hline 2.5 to 5.0 & . & & 2 & 3 & 7 & 9 \\
\hline 5.0 to 7.5 & & & 3 & 3 & 6 & 7 \\
\hline 7.5 to 12.5 & $\ldots$ & $\ldots$ & 3 & 3 & 4 & 4 \\
\hline
\end{tabular}

The results for the root activity measurements are given in Table 3.

TABLE 3: BROWNTOP AND WHITE CLOVER RELATIVE ROOT ACTIVITIES (\%) FOR P UPTAKE AT DIFFERENT SOIL DEPTHS

\begin{tabular}{lllccccc}
\hline & & \multicolumn{7}{c}{ Soil } & Depth & (cm) \\
& & 2.5 & 7.5 & 12.5 & 25 & 37.5 & 50 \\
\hline Browntop $\quad \ldots .+$ & $\ldots$ & 87 & 7 & 3 & 2 & $!$ & 1 \\
White clover & $\ldots .$. & $\mathbf{7 4}^{* *}$ & $\mathbf{1 5}^{* *}$ & 6 & 2 & 2 & 1 \\
\hline
\end{tabular}

Highly significant species differences. 
About $80 \%$ of root activity was in the top $2.5 \mathrm{~cm}$ of soil, where, however, browntop activity was significantly higher than that of clover. At $7.5 \mathrm{~cm}$, clover had a dgndficantly higher value. It is known that in a nutrient-deficient situation plant roots increase at sites where nutrients are more plentiful. This probably accounts, at least in part, for the high concentration of root activity in the P-rich top $2.5 \mathrm{~cm}$ of soil (Table 2). This concentration, together with the lower value of white clover relative to browntop, supports the idea of direct competition for $\mathrm{P}$ between browntop and clover roots.

This concentration of roots and available $\mathrm{P}$ in the top $2.5 \mathrm{~cm}$ of scil raises the question of soil moisture, since this layer is susceptible to drying. As a soil dries out, moisture films become thinner and the diffusion of $\mathrm{P}$ is progressively slowed down. In effect, the availability of $\mathrm{P}$ is reduced.

The moisture content of the top $2.5 \mathrm{~cm}$ of soil of the same browntop-white clover experiment was measured after saturation of the soil. Results are given in Table 4.

TABLE 4: MOISTURE CONTENTS OF THE TOP $2.5 \mathrm{~cm}$ OF SOIL DRYING UNDER CLOVER OR CLOVER PLUS BROWNTOP

\begin{tabular}{lrrrrr}
\hline & \multicolumn{5}{c}{ No. of D rying D ays } \\
& 1 & 2 & 3 & 4 & 5 \\
\cline { 2 - 6 } Clover alone & 25.2 & 23.5 & 19.7 & 18.4 & 17.2 \\
Clover + browntop & 26.0 & 23.7 & 18.1 & 16.7 & 15.1 \\
Differences & +0.8 & +0.2 & $-1.6 *$ & $-1.7^{* *}$ & $-2.1^{* *}$ \\
\hline
\end{tabular}

**Highly significant differences. ,

Browntop significantly decreased the soil moisture to a greater extent than did clover alone.

The above results indicate that browntop can reduce the $P$ available to white clover both by direct competition and indirectly by drying out the top soil and that a reduction in available $\mathrm{P}$ is more detrimental to clover than to browntop. These effects are probably not peculiar to browntop but the extent of these effects produced by other grasses is not well understood. Mouat and Walker (1959), using glasshouse studies, concluded that browntop was a stronger competitor for $\mathrm{P}$ than was ryegrass or cocksfoot, and Lambert (1967) found at Kaikohe that rye= grass reduced the moisture content of the topsoil much mor than did paspalum or Kikuyu grass. 


\section{Ability of Clover to Respond to $P$}

Clover may be well supplied with $\mathrm{P}$ but unable to respond because of some other limiting factor. Shading of clover stolons may be such a factor.

The present studies included pure stands of white clover which became infested with pearl wort (Sagina procumbens L.), a low, creeping weed which contributed at most $4 \%$ of the herbage when mown very low. Despite this, measurements showed that pearlwort had reduced the number of active clover stolon nodes from 331 to 236 per $450 \mathrm{~cm}^{2}$ of ground area. It is the active nodes which Produce new stolons and leaves which reform a clover canopy 'after cutting or grazing. Since the pearlwort growth was small in mass, the result presumably arose from the shading of the stolons. That shading does reduce lateral stolon develop ment is known from American work (Beinhart, 1963).

In much the same manner it was found that stolons growing under a browntop mat about $0.4 \mathrm{~cm}$ thick were quite long but completely devoid of active nodes excepting the terminall node. This extreme shading of clover stolons is probably more characteristic, of browntop than of other grasses and seems to be a very strong factor controlling the performance of clover.

Turning now to conjecture. Clover grows best during the warmer periods of the year which is also the time when browntop tends to become less Palatable to stock. It seems likely that stock, especially sheep will preferentially graze the clover and much of the 'available clover herbage will be that arising from stolon terminal nodes. If these nodes are damaged by this grazing, then there will be little capacity to produce new stolons and leaves because existing stolons remain shaded by the browntop mat.

Browntop may have other effects. Those mentioned, when taken together, are in fact a formidable check to clover growth and $\mathrm{N}$ fixation, since the reduction in $\mathrm{P}$ available to the clover is accompanied by stolon shading at the same time.

The hill situation is likely to show these effects strongly. The $P$ status of the soil is likely to be low because of low fertilization but particularly because of transfer by stack to camping sites which results because varied topography and large paddocks preclude (effective stock control as far as nutrient transfer is. concerned. Set-stocking probably heightens this problem and also allows continuous removal of terminal stolon leaves. Soil types with high $\mathrm{P}$ fixing capacities, such as those formed from volcanic 
ash, will help to keep the $\mathrm{P}$ supply low as also will types such as some of the pumice soils which dry out easily.

\section{REFERENCES}

Beinhart, G., 1963: Effects of environment on meristematic development, leaf area and growth of white clover. Crop Sci., 3: 209-13.

Jackman, R. H.; Mouat, M. C. H., 1972: Competition between grass and clover for phosphate. II. Effect of root activity, efficiency of response to phosphate and soil moisture. N.Z. $/ l$ agric. Res., 15:667-75.

Lambert, J. P., 1967: Pasture species for Northland. Proc. N.Z. Grassld Ass., 29: 78-86

Mouat, M. C. H.; Walker, T. W., 1959: Competition for nutrients between grasses and white clover. I. Effect of grass species and nitrogen supply. Pl. Soil, 11: 30-40. 